\title{
Relationships of the Todai Health Index to the General Health Questionnaire and the Center for Epidemiologic Studies Depression Scale
}

\author{
Noboru Iwata \\ Department of Hygiene and Preventive Medicine, Division of Social Environment, \\ Graduate School of Environmental Science, Hokkaido University, Sapporo \\ Kazuo Saito \\ Department of Hygiene and Preventive Medicine, Hokkaido University School of Medicine, Sapporo
}

\section{INTRODUCTION}

In the United States and some European countries, many researches on psychiatric epidemiology or community psychology based on population surveys have been carried out to obtain basic data on community mental health. These researches have been based on self-rating questionnaires or semistructured interview schedules. Psychiatric epidemiology has been advanced through the introduction of these research instruments, operational classificatory schemes, and population prevalence surveys ${ }^{1-8)}$.

In Japan, however, epidemiologic studies in these areas are sparse. One of the reasons may be due to the fact that there have been few conventional questionnaires applicable to such epidemiologic surveys. Recently, however, the validity and reliability of the Zung self-rating depression scale ${ }^{\text {g) }}$ have been tested by Kawakami and Koizumi ${ }^{10)}$. Several investigations of subjective health status have been performed according to the Cornell Medical Index (CMI), while a few others used the Todai Health Index (THI). Although both the CMI and the THI have been recognized as useful questionnaires for such surveys ${ }^{11}$, they consist of too many items, 195 and 130, respectively. Therefore, research based on these questionnaires is attended with some difficulties.

As self-rating questionnaires, the General Health Questionnaire ${ }^{12,13)}$ (GHQ) and the Center for Epidemiologic Studies Depression Scale ${ }^{14)}$ (CES-D) have been widely applied to such researches in the United States and in European countries. Each of the questionnaires is so brief that it takes only a short time to be completed; thus, they have been easily applicable to many types of surveys. In Japan, neither the validity nor the reliability of either questionnaire has been recognized in samples of adult workers, though Nakagawa and Daibo ${ }^{15)}$ reported that the sensitivity, specificity and overall misclassification rate of the GHQ were $94.2 \%, 76.4 \%$ and $13.7 \%$, respectively, in a comparison between neurotic patients and normal controls.

In the present study the authors examine the relationships between these questionnaires and the THI as a test battery. This paper presents basic data about the nature and the criterion-related validities and reliabilities of the Japanese versions of the GHQ and the CES-D in epidemiologic surveys.

\section{MATERIALS AND METHODS}

\section{Subjects and Research}

The subjects were 2,190 workers in public institutions in Hokkaido, aged 19-63 years. The subjects were asked to complete three self-rating questionnaires, the THI, the GHQ and the CES-D. The research was carried out in September, 1986. Seventeen hundred and forty-three subjects who completed the questionnaires (males: $n=1,626$; females : $n=114$; unknown: $n=3$ ) were analysed.

As a whole, the subjects had a relatively high educational level (all subjects' years of education were 
greater than 12) and were stable income-earners and all full-time employees. Fewer of the subjects had a marital status of separated. Generally, they could be regarded as a representative sample of the Japanese working population, except for the predominance of males (93.3\%).

2. Measurements

The THI was developed as a general health questionnaire with the purpose of supplementing the CMI, which is widely used in Japan ${ }^{16}$. It has 130 items, each of which has three possible responses (and scores), "no (1)", "vague or sometimes (2)", "yes or frequently (3)". It has 12 scales constructed on the basis of the results of factor analysis of 191 items. Each subject is evaluated according to the scale scores by summing up the response values and three discriminant function (DF) values to estimate the tendencies toward psychosomatic disease, neurosis and schizophrenia.

The GHQ was principally designed as a test for the screening of non-psychotic psychiatric illness ${ }^{12}$. This questionnaire has been applied not only to in-patients and out-patients of clinics but also to both general medical care facilities and screening of community populations $\mathrm{s}^{\mathrm{8}, 17,18)}$. Furthermore, it has also been applied to other mental health studies ${ }^{19-21)}$ both in English speaking and non-English speaking countries $^{22,233}$. It has five versions, the full 60 -item one, $30,20,12$-item versions, and a 28 -item scaled version $^{13.24}$. The four possible responses, ranging from "better than usual or not at all" to "much worse than usual or much more than usual" are evaluated by the 0-0-1-1 GHQ scoring method. Each subject is evaluated according to the total score by summing up the response values. The standard cut-off points of the GHQs are $11 / 12,4 / 5,3 / 4,2 / 3$, and $4 / 5$, respectively. The score is considered to reflect one's psychological impairment level. In this study the Japanese version GHQ translated by Nakagawa et al.25) was used.

The CES-D was developed by the National Institute of Mental Health of the United States as a tool intended to identify the group being "at high-risk" of depression in epidemiologic studies ${ }^{14}$. According to Comstock and Helsing ${ }^{26)}$, the scale has 20 items selected to represent the major symptoms in the clinical syndrome of depression, mainly from Zung's depression scale ${ }^{9)}$ and partially from the scales of Beck et al. ${ }^{27)}$, Raskin et al. ${ }^{28)}$ and Dahlstrom and Welsh ${ }^{29}$. The four possible responses to each of the 20 questions in the CES-D scale are weighted from 0 for "rarely or none of the time" to 3 for "most or all of the time". The four positive items, items number 4, 8, 12 and 16, are scored in reverse. Its score correlates well with other indices of depression ${ }^{301}$ and a score of above 16 indicates a high level of depressive symptoms, including both the presence and persistence of the symptoms in the scale ${ }^{26)}$. It has relatively good levels of reliability and validity ${ }^{14,26,31,32)}$. The Japanese version CES-D presented by Shima et al. ${ }^{33)}$ was used in the present study with slight modifications by the author.

3. Statistical analysis

The 12 scale scores and the three DF-values of the THI, scores of the full-item and shorter-item version GHQs (the GHQ-60, GHQ-30, GHQ-28, GHQ-20, and GHQ-12) and of the CES-D were calculated for each subject. The DF-values of the THI were based on the equations of Aoki et ${ }^{1{ }^{15}}{ }^{15}$ and $A o k i^{34)}$, due to their higher screening ability.

Pearson's product-moments correlation coefficients among the scores were calculated to examine the relationships of these questionnaires to each other. Partial correlation coefficients between the THI scales and each GHQ scale and the CES-D were also calculated to examine the relationships among them while controlling the variances of all other scales of the THI.

The discriminant powers of the DF-values of the THI for neurosis and psychosomatic disease are recognized; the correct screening ratios were reported to be $79.8 \%$ and $81.7 \%{ }^{16.34)}$, respectively. The sensitivity and the specificity were calculated for each scale and applied to the standard cut-off point reported previously in comparison with the discriminants of neurosis and psychosomatic disease of the $\mathrm{THI}$ in order to examine their discriminant power as a screening test for these disorders. Comparisons of the GHQs and the CES.D with the DF-value of schizophrenia were not carried out because of the higher probability of incorrect function ratios ${ }^{35)}$.

A principal component analysis with varimax rotation was performed for each pair of the THI scales and each GHQ scale and the CES-D to examine the factor structure. The criterion for a scale to be 
regarded as loading significantly on a factor was taken to be 0.400 .

\section{RESULTS}

Table 1 shows the mean and standard deviation of each score in the present study. In comparison with the results of the THI based on 5,426 workers previously reported by Aoki ${ }^{36}$ ), every age-group of males classified by each 10 years of age, e.g., aged 20-29 years, had lower scores for nearly all scales of the THI than the results of the same age-groups reported by $\mathrm{Aoki}^{36)}$, though the tendencies of the scores among four age-groups were the same as in his report. As a whole, the subjects in this study appear to be healthy ${ }^{35}$. The percentage of the subjects with a DF-value above 0 for neurosis was 7.6 and that for psychosomatic disease was 6.0 for males. More details are reported else where ${ }^{35}$.

The internal consistency coefficients ${ }^{37}$ ) (Cronbach's coefficient alpha) based on the 0-0-1-1 GHQ scoring method (and the 0-1.2-3 Likert scoring method) of the GHQ-60, the GHQ-30, the GHQ-28, the GHQ-20 and the GHQ-12 were $0.93(0.95), 0.87$ $(0.90), 0.86(0.91), 0.85(0.88)$ and $0.76(0.82)$, respectively. The coefficient alpha of the CES-D was 0.79 .

The correlation coefficients between the THI and the GHQs and the CES-D are displayed in Table 2. All correlation coefficients reached a significance level of $p<0.0001$. Among the GHQs and the CES-D,
Table 1 Mean and standard deviation (S.D.) of the 12 scale scores and the three discriminant function values of the THI, the five versions of the GHQ and the CES-D.

\begin{tabular}{lcclcc}
\hline $\begin{array}{r}\text { THI } \\
\text { scale }\end{array}$ & mean & S.D. & $\begin{array}{c}\text { GHQs \& } \\
\text { CES-D }\end{array}$ & mean & S.D. \\
\hline SUSY & 27.063 & 5.837 & GHQ-60 & 7.223 & 7.942 \\
RESP & 13.489 & 3.182 & GHQ-30 & 3.283 & 3.922 \\
EYSK & 13.871 & 3.235 & GHQ-28 & 3.003 & 3.832 \\
MOUT & 12.868 & 2.573 & GHQ-20 & 2.270 & 3.032 \\
DIGE & 12.093 & 2.889 & GHQ-12 & 1.460 & 1.919 \\
IMPU & 16.205 & 3.130 & CES-D & 10.494 & 5.744 \\
LISC & 19.134 & 2.891 & & & \\
MENT & 21.494 & 4.994 & DF value & mean & S.D. \\
DEPR & 13.358 & 3.348 & PSD & -1.4044 & 0.8494 \\
AGGR & 15.950 & 2.162 & NEURO & -1.0408 & 0.6695 \\
NERV & 16.066 & 3.485 & SCHIZO & -0.3048 & 0.6322 \\
LIFE & 17.148 & 3.443 & & & \\
\hline Abbreviation & & & & &
\end{tabular}

Abbreviations. SUSY : many physical symptoms, RESP : respiratory organ complaints, EYSK : eye and skin complaints, MOUT : mouth and evacuation complaints, DIGE : digestive organ complaints, IMPU : impulsiveness, LISC: lie scale, MENT : mental instability, DEPR : depressiveness, AGGR : aggressiveness, NERV : nervousness, LIFE : irregularity of daily life, PSD : discriminant function value of psychosomatic disease, NEURO: discriminant function value of neurosis, SCHIZO : discriminant function value of schizophrenia.

Table 2 Correlations between the THI scale scores and the GHQ and the CES-D scores.

\begin{tabular}{lcccccc}
\hline \multicolumn{1}{c}{ THI scale } & GHQ-60 & GHQ-30 & GHQ-28 & GHQ-20 & GHQ-12 & CES-D \\
\hline SUSY & $.621^{*}$ & .496 & $.626^{* *}$ & .476 & .454 & .498 \\
RESP & $.344^{* *}$ & .262 & $.339^{*}$ & .253 & .242 & .272 \\
EYSK & $.410^{* *}$ & .321 & $.408^{*}$ & .321 & .302 & .350 \\
MOUT & $.371^{* *}$ & .279 & $.363^{*}$ & .267 & .262 & .327 \\
DIGE & $.407^{* *}$ & .336 & $.407^{* *}$ & .331 & .324 & .310 \\
IMPU & $.469^{* *}$ & .425 & $.463^{*}$ & .417 & .422 & .423 \\
LISC & $-.344^{* *}$ & -.322 & -.312 & -.310 & -.313 & $-.330^{*}$ \\
MENT & $.570^{* *}$ & .520 & $.556^{*}$ & .521 & .508 & .550 \\
DEPR & $.672^{*}$ & .653 & .650 & .636 & .621 & $.700^{* *}$ \\
AGGR & $-.322^{*}$ & -.272 & $-.323^{* *}$ & -.262 & -.248 & -.310 \\
NERV & $.338^{*}$ & .311 & $.344^{* *}$ & .305 & .289 & .238 \\
LIFE & $.433^{* *}$ & .379 & .397 & .370 & .359 & $.398^{*}$ \\
\hline PSD & $.502^{*}$ & .431 & $.503^{* *}$ & .418 & .403 & .454 \\
NEURO & $.606^{* *}$ & .581 & $.601^{*}$ & .561 & .551 & .559 \\
SCHIZO & .115 & $.193^{*}$ & .108 & .192 & .182 & $.240^{* *}$ \\
\hline
\end{tabular}

$\mathrm{N}=1,734$. All coefficients are significant at $p<0.0001 .^{* *}$ and * : The greatest and the second greatest correlational values for each THI scale. Abbreviations are the same as in Table 1. 
the GHQ-60 showed the highest correlation coefficient with almost of the THI scales, except for the 'depressiveness', 'many physical symptoms', 'aggressiveness', and 'nervousness'. The 'depressiveness' scale displayed the highest correlation with the CES-D. The 'many physical symptoms', 'aggressiveness' and 'nervousness' showed the highest correlations with the GHQ-28. The GHQ-28 displayed the second highest correlations with almost all scales, except for the 'depressiveness', 'irregularity of daily life' and 'lie scale'; they showed slightly higher correlations with the CES-D than the GHQ-28.

Among the three DF-values, the value for neurosis had the highest correlation coefficient with the GHQ-60 and the second highest correlation with the GHQ-28. The value for psychosomatic disease showed the highest correlation with the GHQ-28 and the second highest correlation with the GHQ-60. The value for schizophrenia showed the highest correlation with the CES-D and the second highest correlation with the GHQ-30.

Partial correlation coefficients between the THI scale and each GHQ scale and the CES-D were calculated while controlling the variances of all other scale scores of the THI. The results were as follows: all of the GHQs and the CES-D showed significant partial correlation coefficients with the 'depressiveness' at $p<0.0001$, and the CES-D showed the highest coefficient. The 'many physical symptoms' were significantly correlated to the GHQ-60, the GHQ-30, the GHQ-28 and the GHQ-20, and showed the highest correlation with the GHQ-28. Partial correlations of all the other pairs did not reach significant levels.

The sensitivities, specificities and correct screening ratios of the GHQs and the CES-D by means of comparison with the discriminatives of the THI are displayed in Table 3 . In comparison with the DF-value of neurosis, the GHQ-28 and GHQ-30 showed the highest sensitivity ; $76.8 \%$, and the CES-D showed the highest specificity and correct screening ratio ; $89.3 \%$ and $87.6 \%$, respectively. In comparison with the DF-value of psychosomatic disease, the GHQ-28 showed the highest sensitivity; $72.7 \%$, and the CES-D showed the highest specificity and correct screening ratio; $87.9 \%$ and $85.8 \%$, respectively.

A principal component solution of all pairs of the 12 scales of the THI with each GHQ scale and the CES-D yielded two factors before the eigenvalue fell below 1.0. Varimax rotations were therefore carried out for the two factors. The varimax rotated factor loadings in a pair of the THI scales and the GHQ-60 are indicated in Table 4. The THI scales were divided into different factors: the scales for psychological conditions; the 'mental instability', 'depressiveness', 'impulsiveness' and 'nervousness' were allocated to the first factor named "psychological symptoms". The 'lie scale' and 'aggressiveness' had significant negative loadings for this factor. The second factor, named "physical symptoms", consisted of the 'respiratory organ complaints', 'digestive organ complaints', 'mouth and evacuation complaints', 'eye and skin complaints' and 'irregularity of daily life'. The 'many physical symptoms' and the GHQ-60 had

Table 3 Sensitivity and specificity of the GHQ and the CES-D \#.

\begin{tabular}{ccccccc}
\hline THI DF-value & GHQ-60 & GHQ-30 & GHQ-28 & GHQ-20 & GHQ-12 & CES-D \\
\hline PSD & & & & & & \\
ST(\%) & 64.6 & 65.5 & $72.7^{*}$ & 61.8 & 60.9 & 54.6 \\
SP(\%) & 82.1 & 79.6 & 79.5 & 81.3 & 83.5 & $87.9^{*}$ \\
CR(\%) & 81.0 & 78.7 & 79.1 & 80.1 & 82.0 & $85.8^{*}$ \\
NEURO & & & & & & \\
ST(\%) & 73.6 & $76.8^{*}$ & $76.8^{*}$ & 76.0 & 68.0 & 66.4 \\
SP(\%) & 83.2 & 80.9 & 80.3 & 82.8 & 84.4 & $89.3^{*}$ \\
CR(\%) & 82.5 & 80.6 & 80.0 & 82.3 & 83.3 & $87.6^{*}$ \\
\hline
\end{tabular}

$\mathbf{N}=1,734$. \#: Values presented are calculated by means of comparison with the discriminant function of the THI, so they do not represent the real sensitivity and specificity of each scale. ": The greatest values among the GHQs and the CES-D. Abbreviations. ST(\%): Sensitivity in comparison with discriminant function of the THI, SP(\%): Specificity in comparison with discriminant function of the THI, CR(\%): Correct screening ratio in comparison with discriminant function of the THI. All other abbreviations are the same as in Table 1. 
Table 4 Factor structure of the THI scales and the GHQ-60 \#.

\begin{tabular}{lccc}
\hline Scale & Factor I & Factor II & Communality \\
\hline GHQ-60 & $.609^{*}$ & $.413^{*}$ & .542 \\
SUSY & $.435^{*}$ & $.779^{\circ}$ & .797 \\
RESP & .139 & $.763^{\circ}$ & .602 \\
EYSK & .307 & $.682^{\circ}$ & .559 \\
MOUT & .201 & $.705^{\circ}$ & .538 \\
DIGE & .227 & $.718^{*}$ & .566 \\
IMPU & $.751^{*}$ & .263 & .633 \\
LISC & $-.595^{*}$ & -.204 & .396 \\
MENT & $.814^{*}$ & .353 & .787 \\
DEPR & $.757^{*}$ & .359 & .702 \\
AGGR & $-.504^{*}$ & -.230 & .307 \\
NERV & $.671^{*}$ & .070 & .455 \\
LIFE & .396 & $.523^{*}$ & .431 \\
\hline Sum of squares of & 3.780 & 3.534 & 7.314 \\
factor loadings & $(29.1 \%)$ & $(27.2 \%)$ & $(56.3 \%)$ \\
\hline
\end{tabular}

\#: Principal component analysis with varimax rotation. ': Significant loading with value above 0.400. Abbreviations are the same as in Table 1. significant loadings for both factors, although the 'many physical symptoms' had higher loading for the 2nd factor than the 1st one while the reverse was true for the GHQ-60.

The results of all other pairs were almost the same, while the allocations of the 'irregularity of daily life' were alternated and the GHQ-30, the GHQ-20, the GHQ-12 and the CES-D displayed significant loadings only for the "psychological symptoms" factor.

\section{DISCUSSION}

The THI consists of about the same number of items for both psychological and physical symptoms, since it was developed as a general health questionnaire with the purpose of supplementing the CMI. Its validity and reliability as a screening tool have been examined in a sample of Japanese workers based on several field surveys and has been recognized to have a relatively good level of validity for the screening of neurosis and psychosomatic disease ${ }^{16.34)}$.

The GHQ and the CES-D were originally developed to detect subjects with a high risk of neurosis and a high level of depressive symptoms,

respectively, so the dimensions measured by the GHQs and the CES-D are somewhat different from those of the THI. However, if the Japanese versions of the GHQs and the CES-D preserve the fundamental nature of their original versions, they would be useful for the measurement of moods or symptoms related to neurosis and psychosomatic disease, because the scores of their original scales have been recognized to reflect the psychological impairment levels of the subjects ${ }^{12 \sim 10,19,20,22)}$ and psychosomatic disease is regarded as a clinical entity of neurosis ${ }^{11}$. In this study, therefore, the authors examined the criterionrelated validities of the GHQs and the CES-D in comparison with the THI.

The coefficient alphas of the five versions of the GHQ and the CES-D were 0.80 or more, so that the internal consistencies (one of the measures of reliability) of the Japanese versions of the GHQs and the CES-D were at a satisfactory level in this study.

All the correlation coefficients of the GHQs and the CES-D with the THI scales were at an extremely high level of significance, $p<0.0001$. In particular, their correlations to the 'depressiveness', 'mental instability' and 'many physical symptoms' displayed high values; their ranges were $0.62-0.70,0.51-0.57$ and 0.45-0.63, respectively. All the correlations with the DF-values of the THI also reached a significant level and the highest values were with the DF-values of neurosis; in the range of $0.55-0.61$, and with the DF-value of psychosomatic disease; the range being 0.40-0.50. Both the GHQs and the CES-D consist of more psychological symptom items than physical symptom items; therefore, it is natural that they demonstrated more consistency with the tendency toward neurosis than with the tendency toward psychosomatic disease exhibiting somatic symptoms rather than psychological symptoms.

Among the GHQs and the CES-D, the GHQ-60 and the GHQ-28 displayed higher correlations with most of the THI scales and with the DF-values of neurosis and psychosomatic disease than the others, although all of them reached a high level of significance. Only the 'depressiveness' scale had the highest correlation with the CES-D. Thus, the GHQ-60 and the GHQ-28 are considered to reflect the quantity of mental and somatic symptomatology measured by the THI and the tendencies toward neurosis and psychosomatic disease more than the others. The CES-D is considered to reflect the depressive symptomatology measured by the THI more than the others. 
For the discriminant powers, the GHQ-28 demonstrated higher sensitivities for the screenings of both neurosis and psychosomatic disease than the others. The CES.D had the highest specificities and correct screening ratios for these diseases. Of the screening tools applied to detect the potential cases in a population, sensitivity is the most important ${ }^{10)}$. Thus, at least in comparison using the THI as the basic criterion, the GHQ-28 is considered to be the most applicable measure in this study.

Since these kinds of instruments are most applicable to the first screening stage of an epidemiologic community survey to detect subjects with higher levels of psychological distress or affective disorders ${ }^{12 \sim 14)}$, the question of whether they can measure quantitative mood or symptom changes is regarded as a matter of great importance. The present results are considered to show that the Japanese versions of the GHQs and the CES-D can measure these factors symptomatologically. Thus, these questionnaires are considered to be applicable to epidemiologic surveys intending to measure the psychological impairment level of a sample of Japanese workers. The GHQ-60 and the GHQ-28 would appear to be superior to other versions of the GHQ and the CES-D as screening instruments.

The limitations of the present results are apparent, since both the GHQs and the CES-D are different from the THI in their design and application in the strict sense, and neither was compared with the clinical ratings in this study. Further studies are needed to ascertain the real validity of the Japanese versions of the GHQs and the CES-D by means of comparing their scores with clinical ratings.

Kawakami and Koizumi ${ }^{10}$ mentioned that practical screening strategies, e.g., the second screening procedure, should be ingeniously devised for the purpose of early detection of clinical psychiatric cases, since more than $80 \%$ of the subjects with a Zung self-rating depression scale score of 51 or above were classified as non-psychiatric cases on the basis of their screening for psychiatric disease. Some limitations in the use of these kinds of questionnaires should be noted since they are not intended to be clinical diagnostic tools. The dimensions measured by these instruments are at the level of self-awareness, so the scores may be influenced by transient mood or feeling changes or by the subject's attitude to response, e.g., due to the influence of social desirability or other such factors.

In summary, as concluded by Radloff ${ }^{14}$, the GHQs and the CES-D are considered to be valuable tools for identifying subjects with a high level of psychological impairment and depressive symptoms, respectively, in epidemiologic population surveys, and for studying the relationships between psychological distress and many other socio-demographic or socio-environmental variables as shown in the study by Lawrence ${ }^{38)}$.

\section{SUMMARY}

In this study the criterion-related validities and the reliabilities of the Japanese versions of the GHQ and the CES-D were examined in comparison with the THI in a sample of adult workers. The results obtained were as follows:

1) The full-item version GHQ and the 28-item scaled version GHQ showed a higher correlation with the THI scales and the discriminant function values in neurosis and psychosomatic disease than did the others.

2) The results of partial correlation analysis between the THI scales and the GHQs as well as the CES-D indicated the strongest relationship between the THI and the GHQ or the CES-D scores to be for the 'depressiveness' scale.

3) For the discriminant power, the 28-item scaled version GHQ had the highest sensitivities for both neurosis and psychosomatic disease.

4) The internal consistencies of both the GHQs and CES-D according to Cronbach's coefficient alpha were at good levels.

These results appear to indicate that both questionnaires had some applicability for use in epidemiologic surveys, especially the 60 -item and 28 -item GHQ. Though the clinical validities of both questionnaires were not ascertained in this study, they are, in such surveys, considered to be valuable tools for identification of groups having high levels of psychological distress. 
Acknowledgments : The authors thank Yuko Okuyama, M.D., Ph.D., for giving us the opportunity of this study. We also thank the club members of "Hokkaido University Wandervogel Verein" for assisting to make the dataset analyzed in this study at the Hokkaido University Computing Center.

\section{REFERENCES}

1) Endicott, J. and Spitzer, R.L.: Use of the Research Diagnostic Criteria and the Schedule for Affective Disorders and Schizophrenia to study affective disorders, American Joumal of Psychiatry, 136, 52-56 (1979).

2) Finlay-Jones, R.B. and Burvill, P.W.: The prevalence of minor psychiatric morbidity in the community, Psychological Medicine, 7, 475-489 (1977).

3) Weissman, M.M. and Myers, J.K.: Rates and risks of depressive symptoms in a United States urban community, Acta Psychiatrica Scandinavica, 57, 219-231 (1978).

4) Weissman, M.M. and Myers,J.K. : Affective disorders in a United States urban community, Archives of General Psychiatry, 35, 1304-1311 (1978).

5) Weissman, M.M., Myers, J.K. and Harding, P.S. : Psychiatric disorders in a U.S. urban community : 19751976, American Journal of Psychiatry, 135, 459-462 (1978).

6) Myers, J.K. and Weissman, M.M. : Use of a self-report symptom scale to detect depression in a community sample, American Journal of Psychiatry, 139, 1081-1084 (1980).

7) Eaton, W.W. and Kessler, L.G.: Rates of symptoms of depression in a national sample, Ameriacn Journal of Epidemiology, 114, 528-538 (1981).

8) Benjamin, S., Decalmer, P. and Haran, D. : Community screening for mental illness : A validity study of the General Health Questionnaire, British Journal of Psychiatry, 140, 174-180 (1982).

9) Zung, W.W.K. : A self-rating depression scale, Archives of General Psychiatry, 13, 508-515 (1965).

10) Kawakami, N. and Koizumi, A.: Validity of self-assessing depression scale in industry, Japanese Journal of Industrial Health, 28, 360-361 (1986). (In Japanese)

11) Suzuki, S., Aoki, S. and Kusakari, J.: Relationship between the scale of the Cornell Medical Index and the Todai Health Index, Japanese Joumal of Public Health, 26, 161-168 (1979). (In Japanese)

12) Goldberg, D.P.: The detection of psychiatric illness by questionnaire, Maudsley Monograph No. 21. Oxford University Press: London (1972).

13) Goldberg, D.P. : Manual of the General Health Questionnaire, NFER-Nelson Publishing Company : Windsor (1978).

14) Radloff, L.S.: The CES-D scale: A self-report depression scale for research in the general population, Applied Psychological Measures, 1, 385-401 (1977).

15) Aoki, S., Suzuki, S. and Yanai, H. : A new trial of making a health and personality inventory, THPI, Japanese Journal of Behaviormetrics, 2, 41-53 (1974). (In Japanese)

16) Nakagawa, Y. and Daibo, I.: Tests of the validity and reliability of the Japanese version General Health Questionnaire and its clinical applications, In: Nakagawa, Y., ed. The theory behind understanding psychiatric and neurotic symptoms using a questionnaire and its clinical applications, Monograph of National Institute of Mental Health, Part 2: National Institute of Mental Health (1982). (In Japanese)

17) Ballinger, C.B. : Psychiatric morbidity and the menopause : Screening of a general population sample, British Medical Journal, 3, 344-349 (1975).

18) Hobbs, P., Ballinger, C.B. and Smith, A.H.W. : Factor analysis and validation of the General Health Questionnaire in women: A general practice survey, British Journal of Psychiatry, 142, 257-264 (1983).

19) Banks, M.H., Clegg, C.W., Jackson, P.R., Kemp, N.J., Stafford, E.M. and Wall, T.D. : The use of the General Health Questionnaire as an indicator of mental health in occupational studies, Journal of Occupational Psychology, 53, 187-194 (1980).

20) Stafford, E.M., Jackson, P.R. and Banks, M.H. : Employment, work involvement and mental health in less qualified young people, Journal of Occupational Psychology, 53, 291-304 (1980).

21) Cox, T., Thirlaway, M., Gotts, G. and Cox, S. : The nature and assessment of general well-being, Journal of Psychosomatic Research, 27, 353-359 (1983).

22) Tennant, C.: The General Health Questionnaire: A valid index of psychological impairment in Australian populations, Medical Journal of Australia, 2, 392-394 (1977).

23) Munoz, P.E., Vazquez, J.L., Pastrana, E., Rodriguez, F. and Oneca, C. : Study of the validity of Goldberg's 60-item G.H.Q. in its Spanish version, Social Psychiatry, 13, 99-104 (1978).

24) Goldberg, D.P. and Hillier, V.F.: A scaled version of the General Health Questionnaire, Psychological Medicine, 9, 139-145 (1979). 
25) Goldberg, D.P.: The detection of psychiatric illness by questionnaire, Maudsley Monograph No. 21. Oxford University Press: London (1972). Translated In: Nakagawa, Y., ed. The theory behind understanding psychatric and neurotic symptoms using a questionnaire and its clinical applications, Monograph of National Institute of Mental Health, Part 1: National Institute of Mental Health (1982). (In Japanese)

26) Comstock, G.W. and Helsing, K.J.: Symptoms of depression in two communities, Psychological Medicine, 6, 551-563 (1976).

27) Beck, A.T., Ward, C.H., Mendelson, M., Mock, J. and Erbaugh, J. : An inventory for measuring depression, Archives of General Psychiatry, 4, 561-571 (1961).

28) Raskin, A., Schulterbrandt, J., Reating, N. and McKeon, J. : Replication of factors of psychopathology in interviews, ward behavior and self-report ratings of hospitalized depressives, Journal of Nervous and Mental Disease, 198, 87-96 (1969).

29) Dahlsrom, W.G. and Welsh, G.S. : An MMPI Handbook, University of Minnesota Press : Minnesota (1960).

30) Goldberg, E.L., Van Natta, P. and Comstock, G.W.: Depressive symptoms, social networks and social support of elderly women, American Journal of Epidemiology, 121, 448-456 (1985).

31) Craig, T.J. and Van Natta, P. : Prevalence and persistence of depressive symptoms in patient and community populations, American Journal of Psychiatry, 133, 1426-1429 (1976).

32) Weissman, M.M., Sholomskas, D. and Pottenger, M. : Assessing depressive symptoms in five psychiatric populations: A validation study, American Journal of Epidemiology, 106, 203-214 (1977).

33) Shima, S., Shikano, T., Kitamura, T. and Asai, M. : New self-rating scales for depression, Clinical Psychiatry, 27, 717-723 (1985). (In Japanese)

34) Aoki, S. : Study of the validity of the health questionnaire, THI : (2) The means of evaluation in the discriminative diagnosis of psychosomatic disease by THI, Japanese Journal of Hygiene, 34, 766-776 (1980). (In Japanese)

35) Iwata, N., Okuyama, Y., Kawakami, Y. and Saito, K. : An analysis of mental and somatic symptoms in public institution workers in Hokkaido: An epidemiological survey by means of the Todai Health Index, THI, Journal of Northern Occupational Health, 36, 21-27 (1987). (In Japanese)

36) Aoki, S.: Study of the validity of the health questionnaire, THI : (1) The quantitative and qualitative differences of subjective complaints by sex and age, Japanese Journal of Hygiene, 34, 751-765 (1980). (In Japanese)

37) Cronbach, L.J.: Coefficient alpha and the internal structure of tests, Psychometrika, 16, 297-334 (1951).

38) Lawrence, E.G.: Correlates of depressive symptoms among a select population of Black men, American Journal of Public Health, 75, 1220-1222 (1985). 


\title{
東大式健康調査票（THI） と一般健康調查票（GHQ） および疫学研究用うつ病スケール（CES-D）との関連
}

\author{
北海道大学大学院環境科学研究科社会環境学専攻衛生学講座 \\ 岩田昇
}

北海道大学医学部衛生学講座

斎 藤 和 雄

某公的機閏従業員2,190名に対し，東大式健康調查票（THI），日本語版一般健康調查票 (GHQ) および度学研究用う つ病スケール (CES-D) を用いて精神・身体的自覚症状に成する調查を行った。すへての調查票に完全回答の得られた 1,743名の GHQ (12，20，28，30，60各項目版) および CES-D の成結と THI の12尺度得点ならびに 3 疾患に関する判 別值との相関関係を唡討し，またTHI を基洹として心身症および神経症に関する判別能力を検討した。

得られた結果は以下のごとくであった。

1) GHQ および CES-D と THI の全尺度および全判別值との相関係数は，すべて高い有意水準 $(p<0.0001)$ であっ た。また60項目版および28項目版 GHQは，ほとんどの相関係数で他より高い值を示した。

2) THI 尺度との偏相関係数による榙封の結果, GHQ 各項目版および CES-D が最も関連しているのは, 抑うつ症状 であった。

3）判別能力では，28項目版 GHQ が心身症・神経症の両方とも最も高い敏感度を示した。

4) $\alpha$-信頼性係数による GHQ および CES-D の内的整合性は十分な水準であった。

以上の結果より,GHQおょび CES-DのTHI との基準関連妥当性が検討され，特に他に比して60項目版および28項目 版 GHQ の有用性が示唆されだ。本研究においては GHQ おょび CES-D の臨床的罗当性を検討していないが，これらの 調查票は少なくとも，より多くの心理的な偪みを抱えている者を同定するための手段として有用であると考えられた。

Key words: Self-rating health scale, Subjective symptoms, Criterion-related validity 自記式健康調查票，自賞症状，基準関連妥当性 